\title{
THE FRAMEWORK OF ANGLO-SOVIET COMMERCIAL RELATIONS: THE BRITISH VIEW
}

\author{
KENNETH M. STARR*
}

\section{INTRODUCTION}

The conduct of Anglo-Soviet trade occurs within a legal framework composed of various factors, including treaties, trade agreements, unilateral trade policies and measures employed by both countries, and the substantive law of each state. Official agreements between the two states have typically been bilateral accords operating principally to establish a legal structure for trade between the two countries. ${ }^{1}$ The modest function of such instruments is to authorize the conduct of trade, leaving to the market mechanism or, as in the case of the Soviet Union, central planning, the actual content of the trade. In addition, each government promulgates trade measures independent of transnational trade agreements and these measures have potential effects upon Anglo-Soviet commercial relations. For example, Britain enforces a prohibition' of certain strategic goods to the U.S.S.R. and employs an export licensing system which may affect commerce between the two states. ${ }^{2}$

Another component of the framework is the substantive law of both states. It is generally the case in English law that corporations which are agencies of a state under their respective charters or constitutions are accorded state immunity. The view that an enterprise can be so constituted as to enjoy the privilege of state immunity was articulated in the case of Krajina $v$. Tass Agency, ${ }^{3}$ which will be explored below. The historical foundation of English practice toward state trading enterprises can be traced to cases involving the East India Company. ${ }^{4}$ In early cases in which the company was sued, courts typically dismissed the actions on the ground of the sovereign status of the company, despite the fact that it was primarily engaged in commercial activities. Sovereign action, occurring subsequent to and resulting from certain commercial arrangements was found, for example, in Nabob of the Carnatic v. East India Co. ${ }^{5}$ In that case, the defendant-company had been assigned certain sity.

* B.A. 1968, George Washington University; M.A. 1969, Brown University; J.D. 1973, Duke Univer-

${ }^{1}$ See generally Hoya, The Legal Framework of Soviet Foreign Trade, 56 MrNw. L. Rev. I (197r).

2 Id. at 28 .

3 [1949] 2 All E.R. 274.

'See Mann, The Law Governing State Contracts, 2I BRst. Y.B. INT'L I. II (I944). The bifurcated nature of the company is indicated in Gibson v. East India Co., 5 Bing. N.C. 262, 272 (1839): "[T] he East India Company have been invested with powers and privileges of a twofold nature, perfectly distinct from each other; namely, powers to carry on trade as merchants, and (subject only to the prerogative of the Crown to be exercised by the Board of Commissioners for the affairs of India) power to acquirc, and retain, and govern territory, to raise and maintain armed forces by sea and land, and to make peace or war with the native powers of India."

${ }_{2}$ Ves. Jr. 56, 59 (I793). In earlier litigation between the same parties, a demurrer had becn sustained at the pleadings stage. I Ves. Jr. $37 \mathrm{I}$ (I79I). 
districts in India from which revenues were to be collected by the company as security for a debt owed to it by the plaintiff. After being restored to financial control of the districts, plaintiff instituted an action, claiming that the defendant had received funds in excess of the debt. The court, however, held that the transactions arose out of a treaty between two sovereigns and that dismissal of the complaint was thus warranted. The governmental character of revenue collection may distinguish Nabob of the Carnatic from cases involving strictly commercial transactions engaged in by instrumentalities of the state. Indeed, it has been suggested that the umbrella of state immunity need not extend to all activities of a public corporation. ${ }^{6}$ Above all, it appears settled that English law has no firm rule granting total immunity from English jurisdiction to foreign states. ${ }^{7}$

The relatively sympathetic attitude toward immunity of state enterprises is perhaps reinforced by the vitality of such organizations in the United Kingdom. Commercial activities carried on by governmental bodies have been conceptually divided into three groups: ( $\mathrm{I}$ ) those conducted by Ministers of the Crown in the exercise of general executive powers; (2) those entered into by statutory boards or corporations subject to ministerial control although not necessarily occupying an agency relationship; and (3) those conducted by statutory boards or corporations not under the control of Ministers but which act as government agents. ${ }^{8}$ It seems to be established that at least as to the latter, the board or corporation will be treated as a private entity if it is operating for its own benefit. ${ }^{9}$ The two previous types of organizations may properly claim immunity from foreign' courts' jurisdiction, at least if the body acted without intent to create legal obligations, although the absence of such an intent is not to be presumed. ${ }^{10}$

The framework of Anglo-Soviet commercial relations also includes the substantive law of the Soviet Union. Fundamental to any consideration of bilateral commercial intercourse is the fact that under Soviet law external trade is a state monopoly. ${ }^{11}$ In fact, as in the case of the U.S.S.R., all other Comecon countries employ economic systems in which the means of production are owned by the state and in which foreign trade is centrally planned. ${ }^{12}$ State monopolization of foreign commerce was introduced in the U.S.S.R. by decree in IgI8 and was subsequently included in the Civil Code and the Constitution of $1936 .^{13}$

It should be noted, however, that state monopolization of trade does not normally

\footnotetext{
${ }^{\circ}$ See S. Sucharitkul, State Imanumities and Trading Activities in International Law im4 (I959).

Id. at 165 .

${ }^{8}$ Fawcett, Legal Aspects of State Trading, 25 BRIr. Y.B. INT'L L. 34, 37 (1948).

Id. at 44 .

${ }^{20} \mathrm{Id}$. at 43 .

11 Sucharitrul, stipra note 6, at 152 . See K. Grzybowski, Soviet Private International Law 7 (I965); Knapp, The Function, Organization and Activities of Foreign Trade Corporations in the European Socialist Countries, in The Sources of International Trade 53 (C. Schmittoff ed. I964).

${ }^{12}$ See generally Hoya, supra note I, at 2. See also GRzYBowski, supra note I1, at 72.

${ }^{13}$ Szászy, State Trading Activities in Hungary, 20 VAND. L. Rev. 393, 4r4 (1967). See Grzybowskr, supra note $\mathrm{II}$, at 72 .
} 
entail the actual conduct of trade in the state's sovereign capacity. ${ }^{14}$ In practice, Soviet foreign trade is conducted largely by trade corporations which have separate legal capacity to make contracts and to become involved in litigation. ${ }^{15}$ In addition, Soviet trade delegations in various countries represent the Soviet state itself, specifically as part of the Ministry of Foreign Trade. Regarded as part of the Soviet diplomatic delegation, the trade delegation has broad powers to bind the Soviet state in contracts abroad. ${ }^{16}$ As part of the governmental apparatus, the trade delegation is not an independent juridical entity; consequently, unless relevant treaties provide to the contrary, the trade delegation may successfully invoke the doctrine of sovereign immunity. ${ }^{17}$

\section{I}

\section{Anglo-Soviet Trade Agreements}

Inasmuch as a significant part of the structure of bilateral trade relates to official governmental agreements, each of the several accords will be discussed in turn.

\section{A. Trade Agreement of I92I}

The I92I agreement, made in contemplation of a formal peace treaty between the U.K. and Russia which would regulate future economic and political relations, purports to provide only a legal framework within which trade can occur. ${ }^{18}$ No commercial commitments are exacted from either contracting party. ${ }^{19}$ The substance of the agreement provides for the removal of "all obstacles hitherto placed in the way of the resumption of trade" between the two countries and for non-discriminatory treatment of such trade "as compared with that carried on with any other foreign country ...."20 The agreement further provides that each party may designate

\footnotetext{
${ }^{14}$ See Szászy, supra note 13 , at 415.

${ }^{16}$ Hoya, supra note $I$, at 2. As to Soviet corporations, see generally Hazard, Soviet Government Corporations, 41 Mich. L. REv. 850 (I943). See also GrzYBowski, stupra note II, at 72-80; Knapp, stlpra note II, at 6r-69.

${ }^{10}$ Berman, The Legal Framework of Trade Between Planned and Market Economies: The SovietAmerican Example, 24 LAw \& CoNTEMP. ProB. 482, 486 (1959). See generally Knapp, supra note II, at $54-55$.

17 Berman, supra note 16 , at 486 .

${ }^{18}$ In addition to establishing a legal framework for trade, however, the agreement's provisions also relate to post-hostilities concerns, such as clearance of mines from seas adjacent to the parties' coasts and renewal of exchange of private correspondence through the mails and telegraph under regulations in existence prior to I914. Concern regarding recent political events is evidenced by two conditions to which the agreement was made subject: $(x)$ that each party refrains from hostile action and from carrying on official propaganda activities against the other, and (2) that citizens of one party situatcd within the territory of the other be permitted to return.

${ }^{10}$ Commitments which are incurred by the contracting partics include granting full faith and credit to official documents, such as "[p]assports, documents of identity, powers of attorney," of the other party and agreement to refrain from attachment of "gold, funds, securities or commodities" which do not belong to the country of destination when such may be exported from one country in payment for imports from the other party. Trade Agreement Between the United Kingdom and the U.S.S.R., Mar. 16 , I921, 4 L.N.T.S. I27, I33, I34.

${ }^{20} 4$ L.N.T.S. at 129.
} 
persons to enter and carry on trade within the other party's territory. Such traders are to be "exempted from all compulsory services whatsoever ....," and are granted rights of access to communications facilities. The agreement concludes with a recognition "in principle" by both parties of liability to compensate private persons who have supplied goods or services to the other party.

\section{B. Temporary Commercial Agreement of 1930}

Subsequent to the formulation of a treaty of commerce and navigation in 1924, which remained unratified by the U.K., ${ }^{21}$ the two countries in $193^{\circ}$ executed a temporary commercial accord as an interim step prior to concluding a proposed, formal Treaty of Commerce and Navigation. ${ }^{22}$ The agreement is particularly significant in that it provides for establishment of a Soviet trade delegation in the U.K. and the extension of diplomatic immunity to specified members of the delegation. Similar to the 1924 instrument, the agreement called for each party to provide all rights and privileges to the other signatory which were granted to subjects, citizens, or juridical persons of any other foreign state. ${ }^{23}$ This most-favored-nation provision, however, was subject to three exceptions, each of which benefited the U.S.S.R.'1 Under article 2, there is granted to the Soviets the right to establish a trade delegation in London having as its objects, among others, "to control, regulate, and carry on ... trade with the United Kingdom for and on behalf of the Union of Soviet Socialist Republics."25 Given its function as a governmental agency, the trade delegation would have its responsibilities for transactions concluded by the trade representative or authorized persons assumed by the Soviet government. ${ }^{26}$ This responsibility did not extend, however, to "acts of State economic organisations which, under the laws of the Union of Soviet Socialist Republics, are exclusively responsible for their own acts ...."27 Responsibility of the Soviet government for the delegation's activities appeared somewhat illusory, however, by virtue of article 2, section 6 , which provided that all issues arising out of commercial transactions entered into by the trade delegation were to be determined by courts of the U.K. "in accordance with the laws thereof."28 Under English law, no action against a sovereign state may be maintained un-

\footnotetext{
${ }^{21}$ J. Triska \& R. Slusser, The Theory, Law, and Policy of Soviet Trenties 77 (1962).

22 Temporary Commercial Agreement Between the United Kingdom and the U.S.S.R., Apr. 16, 1930, preamble, ror L.N.T.S. 410 [hereinafter cited as 1930 Temporary Commercial Agreement].

${ }^{23}$ Id., art. I, Ior L.N.T.S. at 410.

24 The provision excepted from its coverage the trade provisions in treaties between the U.S.S.R. and "[states], the entire territory of which ... . formed in all respects an integral part of the former Russian Empire or with the continental border [s] tates in Asia;" those rights granted to any third country forming part of a customs union with the U.S.S.R.; or the privileges accorded to border States "with respect to local trade between the inhabitants of the frontier zone." Id., art. I, Ior L.N.T.S. at 4ro-r2.

${ }^{25}$ Id., art. 2, Ior L.N.T.S. at 412. See generally Comment, The Anglo-Soviet Commercial Agreement, i7 The LAW Times 60-6r (193I).

${ }^{20} 1930$ Temporary Commercial Agreement, art. 2, $\$ 4$, IOI L.N.T.S. at 412.

${ }^{27}$ Id., art. 2 , Ior L.N.T.S. at 412.

${ }^{28}$ Id., art. 2, $\$ 6$, IOI L.N.T.S. at 4 I2. This seems to be an exception to normal Soviet practice. See generally GrzYBowskI, supra note II, at 89 .
} 
less the state voluntarily submits to the court's jurisdiction. ${ }^{29}$ It is unclear, therefore, whether the remedial provisions of article 2, section 6, actually granted a remedy not subject to the condition of voluntary submission by the Soviet government. ${ }^{30}$ The remedial provisions of the agreement are complicated further by the "Additional Protocol" to the instrument executed on the same day. ${ }^{31}$ The Protocol purports to limit opportunities for the trade delegation to claim immunity granted by article 2 , section 2, to instances other than those "in connexion with any proceedings ... arising out of commercial transactions entered into in the United Kingdom by the Trade Delegation ...."32 Explicit reference was made to article 2, section 6, a factor tending to indicate an intent by the parties to expose the delegation to English jurisdiction in litigation arising out of commercial transactions. Consequently, immunity was purportedly granted to the delegation as to all functions it was to discharge as outlined in article 2, section 3, except to the carrying on of trade between the two countries.

The Temporary Agreement was short-lived despite its liberal provisions. The British government denounced the instrument on October 17 , 1932, and, pursuant to article $7{ }^{33}$ the agreement terminated on April 16 , x933. The apparent reason for the British action was the direct conflict between the trade monopoly of the Soviet government and the most-favored-nation clause. ${ }^{34}$ Nevertheless, an accord was reached during the following year which revived the most-favored-nation treatment between the two states. ${ }^{35}$ Interestingly, the continuing validity of this subsequent agreement is subject to some dispute, and the present most-favored-nation treatment may not be founded upon a binding treaty obligation. ${ }^{36}$

\section{Protocol of Agreement on Questions of Trade and Finance of 1947}

An example of a trade accord relating to transfers of specific commodities is provided by the Protocol of Agreement signed in Moscow on December 27, 1947. The instrument provided, in part, for the importation of grain by the U.K. and assurance of a supply of certain railroad supplies from the U.K. to the U.S.S.R. during I948. The U.K. also undertook to exercise its powers to ensure that contracts for delivery of equipment to the Soviets "shall be signed in good time and carried

\footnotetext{
${ }^{20}$ Cf. The "Bulgaria," [rg64] 2 Lloyd's List L.R. 524 (Admiralty Div.); Mighell v. Sultan of Johore, [1894] I Q.B. I49, 70 L.T.R. (n.s.) 64 (I893).

${ }^{30}$ See Comment, supra note 25 , at 60 .

${ }^{31}$ ror L.N.T.S. 418 (1930).

32 Id.

${ }^{33}$ Article 7 provides in pertinent part: "The present Agreement . . . shall remain in force until the coming into force of a commercial treaty between the United Kingdom and the Union of Sovict Socialist Republies, subject, however, to the right of either Party at any time to give notice to the other to terminate the Agreement, which shall then remain in force until the expiration of six months from the date on which such notice is given." 1930 Temporary Commercial Agreement, art. 7, ror L.N.T.S. at $4 \mathrm{I} 6$.

${ }^{34}$ TRISKa \& SLUSSER, supra note 2I, at 328.

${ }^{35}$ See Hoya, supra note 1 , at 24 .

${ }^{30}$ See id.
} 
out by the prospective dates of delivery specified . ..."37 In addition to the matter of deliveries, each party, "being desirous of extending trade between the two countries ....,"38 agreed to commence negotiations for the purpose of supplying the U.S.S.R. with specified goods. The agreement also provided that if the value of Soviet orders placed for equipment did not reach half of the total value of merchandise authorized for sale, the U.S.S.R. would "have the right to reconsider its undertaking relating to the making available ..." to the U.K. of a specified quantity of grain. ${ }^{39}$ The sepcificity of the agreement is further indicated by article 5, which governs the financing and method of payments under the contracts, and article 6, pertaining generally to facilitating the transportation of goods. ${ }^{40}$

\section{Five Year Trade Agreements}

Contemporary practices between the two countries are reflected in the first five year trade agreement signed in Moscow on May 24, I959. ${ }^{41}$ The agreement indicates that an increase in trade between the two countries is anticipated, although no minimum trade commitments are established. In addition to British imports of Soviet goods made under the Open General Import License, ${ }^{42}$ the British Board of Trade and the Soviet Trade Delegation are authorized to establish "quotas on an appropriate basis for the import into the United Kingdom of any Soviet goods not subject to Open General Import Licence ...." "*3 Under the agreement, unlike the I947 Protocol," the contracting parties do not undertake "to ensure" deliveries of commodities, a characteristic typical of contracts between centrally-planned economies. ${ }^{45}$ However, certain features patterned after the socialist group model of arrangement are present in the instrument, such as the duration for a specified, limited period; incorporation of a provision calling for fixing of quotas on an annual basis; and provision for annual meetings of official representatives of the two governments to review the agreement and to prepare recommendations to one or both of the parties. ${ }^{46}$ However, it should be noted that the socialist pattern is not strictly followed since the terms for deliveries of goods are left to negotiations between the trading entities in the two countries. ${ }^{47}$

\footnotetext{
${ }^{37}$ Protocol of Agreement on Questions of Trade and Finance Between the United Kingdom and the U.S.S.R., Dec. 27, I947, 91 U.N.T.S. I13, I24-26.

${ }^{38} I d$., 9 I U.N.T.S. at 126 .

${ }^{30} 1 d$.

${ }^{10}$ Id., 9I U.N.T.S. at $x_{2} 8-32$.

"Five Year Trade Agreement Between the United Kingdom and the U.S.S.R., May 24, 1959, 374 U.N.T.S. 306 [hereinafter cited as Five Year Trade Agreement]. See generally Schmitthoff, Commercial Treaties and International Trade Transactions in East-West Trade, 20 VAND. L. REv. 355, 366-68 (1967).

"Five Year Trade Agreement, art. 2, 374 U.N.T.S. at 306.

${ }^{13}$ Id., art. 2, $\$ 2,374$ U.N.T.S. at 308 .

"See notes 37-40 supra and accompanying text. Another point distinguishing the two agreements was the omission in the I959 agreement of a most-favored-nation clause found in the agreements of I930 and 1934 .

${ }^{65}$ See Schmitthoff, supra note $4 \mathrm{r}$, at 368 .

${ }^{10}$ Id. at 367 .

${ }^{47}$ Id. at 368 .
} 
The five year agreement was not perceived as the replacement for the prior comprehensive agreement, namely the Temporary Trade Agreement of $19344^{48}$ Indeed, article 8 of the former measure provides that during 1960 both parties will begin negotiations concerning a Treaty of Commerce and Navigation which "will replace the Temporary Trade Agreement." ${ }^{39}$ Consequently, the parties apparently intended that the I934 accord and the five year agreement remain in effect concurrently. As a result, despite the omission of a most-favored-nation clause in the 1959 accord, the earlier instrument, which contained such a provision, was arguably sufficient to continue preferential treatment.

The 1959 agreement, due to expire in 1964 , was prolonged for another five year period by virtue of execution of a protocol in 1964 , which continued the agreement's life until June 30,1969 . Notably, the protocol, as well as the r959 accord, contained no termination provision analogous to that contained in article 7 of the $193^{\circ}$ Temporary Agreement, whereby either party could terminate the agreement after six months notice. ${ }^{50}$.

In 1969 , the governments "noting with satisfaction the considerable expansion of trade"5I between the Soviet Union and the U.K., entered into a Long-Term Trade Agreement whereby both governments agreed to "facilitate the exchange of goods and services..., subject to the essential security interests of each country." ${ }^{12}$ The primary means of implementation was an undertaking to encourage and facilitate the execution of trade agreements between the Soviet Foreign Trade Organizations and British firms, to work toward eliminating British restrictions on Soviet imports, and to arrange for the Soviet Trade Delegation and the British Board of Trade to establish "an appropriate basis for the import . . . of goods not covered by open licensing arrangements." ${ }^{\text {"In }}$ In turn, the Soviets "expect[ed]" that the Soviet Foreign Trade Organizations "will place, on normal commercial conditions, substantial orders in the United Kingdom for a wide range ..." of products (emphasis added). The emphasized language may suggest that in commercial transactions the Soviets would not invoke the doctrine of sovereign immunity in actions brought subsequent to entering into a trade agreement, although the language could be construed simply to denote Soviet willingness to make purchases in British markets at market prices.

The agreement, which, interestingly enough, makes no provision for mostfavored-nation treatment, will govern Anglo-Soviet trade relations until December 31, 1975, at which time the accord will be extended on an annual basis automatically, unless either government gives notice of termination as prescribed by the agreement.

\footnotetext{
${ }^{18}$ See notes $35-36$ supra and accompanying text.

10 Five Year Trade Agreement, 374 U.N.T.S. at 312.

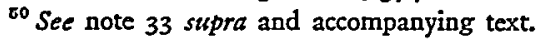

${ }^{51}$ Long-Term Trade Agreement Between the United Kingdom and the U.S.S.R., June 3, 1969, preamble, [1969] Gr. Brit. T.S. No. 92 (CMND 4r32), reprinted at 8 INTERNationat. LeGal MateRials I30I (1969) [hereinafter cited as Long-Term Trade Agreement]. Interestingly, there is no provision for most-favored-nation treatment in the 1964 agreement. See generally Hoya, supra note 1, at 23-24.

${ }^{62}$ Long-Term Trade Agreement, art. I(2), [1969] Gr. Brit. T.S. No. 92 (CMND ${ }_{4132)}$ at 2.

${ }^{53} I d .$, art. $3(I)$ and (2), [rg69] Gr. Brit. T.S. No. 92 (CMND 4132 ) at 2-3.
} 
British willingness to continue the existing framework of Anglo-Soviet trade seems somewhat remarkable since the U.K. has perennially suffered from a trade imbalance with the Soviets. ${ }^{54}$ Besides the obvious reluctance by Soviet officials to purchase British goods liberally, another factor contributing to this condition is the Soviet rule which prevents foreign companies from establishing subsidiaries in the U.S.S.R. in competition with State enterprises. ${ }^{55}$ In contrast, British regulations provide for the establishment of foreign investments in the U.K., subject to governmental approval and to certain exchange control regulations. The latter regulations, however, do not discriminate among U.K. trading partners. ${ }^{56}$

The persisting trade imbalance has been a source of considerable British concern. Thus, a suggestion was made in the House of Commons that British purchases of Soviet goods be reduced "unless [the Soviets] demonstrate a measure of reciprocity towards British manufactured goods." ${ }^{.57}$ In light of this unfavorable trade situation, British officials pressed the Soviets to institute measures necessary to achieve a closer balance in trade. ${ }^{58}$ In addition, certain stop-gap marketing techniques were periodically employed by the British to stimulate exports to the U.S.S.R. For example, in I966, the Board of Trade rendered "extensive support" to the British Industrial Fair held in Moscow, an event which the President of the Board of Trade characterized as having "attracted immense interest." in the House of Commons, the list of goods restricted from sale to the Soviets was kept under "constant review" to ensure discontinuation of a specific restriction when strategic considerations no longer demanded its existence."

Presumably, the "necessary measures" warranting Soviet adoption would simply entail governmental decisions to expand purchases of British goods. In this regard, in 1964, then Secretary Heath expressly requested the Soviet Minister for Foreign Trade to increase the scale of Russian purchases. In his reply to Mr. Heath's request, "Mr. Patolichev confirmed that the competent Soviet authorities would act in accordance with [the] request." ${ }^{31}$ Despite this assurance, subsequent

\footnotetext{
54 The trade imbalance is reflected by the following figures for two distinct periods, 1969-1972, and 1963-rg65. The figures are found in various volumes of Parliament Debates, House of Commons. IMPORTS (from U.S.S.R.)

I963 $\quad$ \& 96.8 million

$1964 £ 97.0$ million

$1965 \quad$ f 118.9 million

I969 £ 196.2 million

$1970 \quad f$ 210.0 million

I971 $£ 205.0$ million
} 
trade figures belie any conclusion that the Soviets are pursuing a policy designed to achieve a trade balance with the U.K. ${ }^{62}$

\section{II}

\section{State Trading Activities and Diplomatic Immunity}

Traditionally, British courts extended diplomatic immunity to diplomats engaged peripherally in private commercial activities. It is not unusual, therefore, that foreign state agencies appear to have been exempt from local jurisdiction even with respect to commercial activities. However, an early exception to this trend insofar as AngloSoviet trade is concerned arose under the rg2r Trade Agreement between the British and Soviet governments. The case of Fenton Textile Association v. Krassin ${ }^{03}$ involved a suit against the head of the Russian trade delegation in England to obtain the balance of an amount owed for certain goods sold. The trade accord had been executed prior to de jure recognition of the Soviet government by the U.K., and, accordingly, by its terms did not extend diplomatic immunity to the trade delegation. ${ }^{64}$ Nevertheless, the defendant applied to set aside service of process on the ground that he was the authorized representative of a foreign state and thus entitled to immunity. The Court of Appeal rejected the defendant's contention on two grounds, first, that the defendant had not been recognized by the British government in any capacity other than that of official agent, and second, that the rights granted to the trade officials were defined in the agreement, which did not provide for immunity from civil process.

Although not expressly involving the issue of diplomatic immunity, the case of Luther $v$. Sagor" raised the question' of the extent of "recognition" afforded to the Russian government by virtue of the presence of Mr. Krassin in England both prior and subsequent to execution of the r92I Trade Agreement. The case turned upon the validity in the English courts of a rgr8 decree of the Russian government purporting to expropriate certain properties, which at the time were owned by a Russian company, the majority stockholder of which was an English enterprise. Despite the presence of Krassin in England for the purpose of conducting negotiations which subsequently culminated in the trade accord, the court held that the decree could not be recognized as a valid legislative action since Krassin's mere authorized presence in England could in no manner constitute British recognition of the Russian government. However, subsequent to execution of the trade agreement, the court

${ }^{82}$ See note 54 supro.

${ }^{43}{ }_{3} 8$ T.L.R. 259 (I92I).

os The agreement did provide for exemption of the Russian agents from either central or local taxation, as well as immunity from search and arrest. For discussion of the legal implications of the 1921 accord, see generally Wilson, British Recognition De Facto and De Jure of the U.S.S.R., 28 AM. J. INT'2 L. 99 (r934).

${ }_{65}$ Aksionainoye Obschestvo A.M. Luther v. James Sagor \& Co., [192I] r K.B. 456, I25 L.T.R. 705, 37 T.L.R. 282 (1920), rev'd on other grounds [192I] 3 K.B. 532, 125 L.T.R. 710, 37 T.L.R. 777 (C.A. II92I). 
reversed its previous position, on the basis of the conclusion of the agreement and a letter from a British official to the effect that the British government had extended de facto recognition to the Soviet government. The effect of de facto recognition ${ }^{66}$ was to validate retroactively the effect of the decree in Igr8.

The result in Luther $v$. Sagor undermines the logic of the court in Fenton Textile. ${ }^{67}$ Since execution of the trade agreement constituted de facto recognition by the British government, it is arguable that official Soviet representatives thereafter enjoyed traditional diplomatic immunities, which Krassin was claiming in Fenton Textile, despite the more restricted provisions of the agreement itself. Since the agreement did not expressly reject the conferring of such immunities, it was, at the least, plausible that the agreement did not exclude such immunities by implication, especially since the mutual understanding by the governments of the agreement's effect was apparently that the accord constituted de facto recognition. Consequently, any official representative properly within the territory of the other nation arguably could invoke diplomatic immunity.

The British courts' attitude toward state trading companies, as distinguished from business-oriented diplomatic personnel or trade delegations, is reflected in a decision, strongly relied upon by the court in the landmark decision of Krajina $v$. The Tass Agency, ${ }^{68}$ involving the United States Shipping Board as defendant. ${ }^{69}$ In an effort to exempt itself from British jurisdiction, the Board, a department of the United States government engaged in ordinary commercial shipping, had filed a certificate from the United States' ambassador and an affidavit of the defendant's legal advisor purporting to define the legal status of defendant as a department of the government and hence not an independent legal entity. The Court of Appeal, per Bankes, L.J., allowed the defendant's application, and the action was stayed. The court minimized the relevance of the fact that the particular ship involved was engaged in private trading since the plaintiff attempted to have the court obtain in personam jurisdiction over a "body representing a sovereign State." Consequently, it is manifest that an organization or department of government does not necessarily lose its status of immunity upon engaging in functions properly categorized as private and commercial in nature. This approach appears contrary to that employed earlier in the East India Company cases, in which the courts ostensibly attempted to determine, in light of the company's dual nature, whether the conduct engaged in related to the commercial or sovereign functions of the enterprise. However, the difference in approach appears less dramatic when it is recognized that the earlier cases did not involve exclusively transnational institutions. Since the East India

\footnotetext{
${ }^{\circ 0}$ Recognition was deemed by the court to have retroactive effect relating back to the establishment of the Soviet government.

${ }^{07}$ See note 63 supre and accompanying text.

${ }^{\circ B}$ Sce note 72 infra and accompanying text.

${ }^{60}$ Compania Mercantil Argentina v. United States Shipping Board, 93 L.J.K.B. (n.s.) 8I6, I3I L.T.R. (n.s.) $3^{88}$ (C.A. 1924).

${ }^{70} 93$ L.J.K.B. (n.s.) at 8 r7, I3I L.T.R. (n.s.) at 389 . See generally Sucharitrul, stupra note 6, at I32.
} 
Company was a British enterprise, a proper frame of reference existed for the purpose of categorizing the company's activities. However, whether a particular function is a matter of state or simply a private affair is at least in part a function of the political system involved. ${ }^{71}$ Consequently, reliance upon statements of government officials regarding the official nature of the particular enterprise would appear, in the absence of formal agreements between states governing the subject, an appropriate dispositive approach.

As suggested above, the landmark decision regarding immunity from suit of a state enterprise was handed down in 1949 in the case of Krajina $v$. The Tass Agency. ${ }^{72}$ In that case, plaintiff instituted a libel action against defendant, which published a weekly newspaper in the U.K. Tass, after entering a conditional appearance, applied to set aside plaintiff's writ on the ground that it was a department of the Soviet government entitled to immunity from suit. As in the case of United States Shipping Board, an ambassadorial intervention occurred; the Soviet ambassador certified that the agency constituted a department, although it was empowered to exercise the rights of a legal entity. The Court of Appeal allowed dismissal of the action, holding that even if Tass was a governmental department enjoying a separate legal status, it did not automatically follow that it was deprived of the right to assert sovereign immunity. ${ }^{73}$

The legal basis of Krajina is somewhat difficult to explain for two reasons. First, as mentioned above, Tass was granted a separate juridical existence, although the statute establishing Tass described it as "the central information organ of the U.S.S.R.[,] . . . attached to the Soviet of People's Commissars of the U.S.S.R."74 However, another provision of the same statute stated that "the telegraphic agency of the U.S.S.R. and the telegraphic agencies of the Union Republics enjoy all the rights of a juridical person." ${ }^{\text {"75 }}$ The plaintiff contended that the doctrine of sovereign immunity is inapplicable since Tass has a separate legal existence from that of the sovereign and that, therefore, the case was distinguishable from United States Shipping Board, since in that case the Board was clearly a governmental department not enjoying a separate juridical status. Secondly, Tass on two occasions registered in the U.K. under the Registration of Business Names Act, first as the agent of a "foreign firm," and secondly, as an individual doing business in the United Kingdom. The statute purported to regulate the conduct of domestic or foreign "business" enterprises (emphasis added), rather than governmental departments. Consequently, the plaintiff argued that by registering under the statute, Tass "has said that it is either a Russian firm or a Russian corporate entity ...."?78

Despite the inferences which could reasonably have been drawn from Tass'

\footnotetext{
${ }^{7}$ SuchartTKUL, supra note 6, at ro4.

${ }^{72}$ [1949] 2 All E.R. 274.

${ }^{73} \mathrm{Id}$. at 280 .

${ }^{74}$ Id. at 276 .

${ }^{75} 1 d$. at 277 .

${ }^{70} \mathrm{Id}$. at 278 .
} 
registration, an action which would appear appropriate since the enterprise was engaged in the publication of a newspaper which was "widely distributed,"77 the court refrained from inferring that Tass, by virtue of registering, was not for purposes of being sued a department of government. Nor did the court find it necessary to rely on the nature of 'Tass' activities in the U.K. to rebut inferences that it constituted a commercial enterprise. For example, only casual reference was made to the fact that the publication involved, The Soviet Monitor, was distributed free of charge to recipients, ${ }^{78}$ a factor tending to indicate discharge of the governmental function of providing information or propagandizing.

On the contrary, the court indicated that the "nature of Tass," and consequently the outcome in the case, depended upon the organization's charter or constitution, thereby necessitating resort to "Russian statutes and to any relevant evidence that is adduced as to Russian law ... to determine whether or not Tass is a separate legal entity." "I9 It determined that in addition to the statute previously discussed, ${ }^{80}$ "relevant evidence" included the ambassador's statement to the effect that Tass was a department of government which exercises the rights of a legal entity. This statement, potentially damaging to Tass, was also deemphasized by the court. The mere statement by the ambassador that the agency is a juridical entity was simply deemed not to be conclusive. Consequently, contrary to the court's assertion that United States Shipping Board was being followed, it is clear that the decision did not rigorously apply the rationale of that decision, since in that case the ambassador's affidavit was considered dispositive of the question of the Board's juridical status. In Krajina, on the other hand, the court felt unjustified in treating the ambassador's statement as conclusive. Furthermore, even if it were determined that Tass enjoyed a distinct juridical status, the court noted that such would not necessarily result in depriving Tass of its immunity. The critical consideration is whether a court can conclude that a sovereign has intended to relinquish immunity.

Prior to Krajina, it had been established that the nature of activities engaged in by a governmental authority was not conclusive for the immunity question. The Parlement Belge ${ }^{81}$ and The Porto Alexandre ${ }^{82}$ held that the fact that trading activities are engaged in is an insufficient basis to deprive a government agency of its claim to immunity. Consequently, in Krajina, the lack of importance attributed to 'Tass' registration in' the Business Names Register appears less significant in light of this decisional law background. The primary significance of the case seems rather to lie in the modification of the Shipping Board rationale and in the attachment of a strong presumption of sovereign immunity to a government agency unless the intent of the sovereign authority to relinquish its presumed immunity is established. ${ }^{83}$

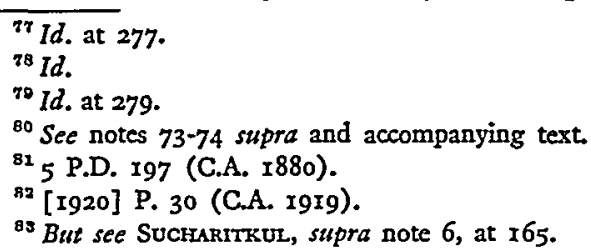


Subsequent to the court's decision in Krajina, brief debate with respect to the case was heard in the House of Commons. In this regard, Mr. Wilson Harris inquired whether the government was considering amendment of the immunity law in such cases. Mr. Harris was informed by the Minister of State, Mr. McNeil, that no action was then contemplated. Clearly, Mr. McNeil was unalarmed by the case, despite Mr. Harris' fears of proliferation of libelous articles "with cornplete impunity." In turn, Mr. Eric Fletcher inquired whether the Minister concurred in the view that the law of immunity is "quite out of date in modern conditions in which States take part in a great many activities ...." Mr Mr. McNeil offered no direct answer.

Leave to appeal to the House of Lords was granted in Krajina, and subsequently, Lord Vansittart moved for Papers. ${ }^{85}$ Following extended debate, however, Lord Vansittart withdrew his motion. ${ }^{86}$ The tone of the debate in the House of Lords indicates disenchantment with the particular result of the doctrine of state immunity, namely a remediless victim of libel, rather than a fundamental disagreement with the doctrine itself.

Without attempting a direct change in the law, but to respond to a subsequent libelous publication in the Soviet Monitor, the British government "addressed to the Soviet Embassy requesting an assurance that if, in future, a dispute should arise between a private person .... and the Tass Agency ... [the agency] would, as a condition of continuing to operate in this country, either waive their immunity from suit or submit to arbitration." 87 The Soviets refused and temporarily ceased publication.

Despite the temporary alarm generated by Krajina, significant legal changes were not forthcoming, except with respect to diplomatic agents in 1964. As to the law of diplomatic immunity, adoption of the 1964 Diplomatic Privileges Act operated to eliminate the immunity defense as to diplomatic agents engaging in "an action relating to any professional or commercial activity . . . outside his official functions."88 This enactment modifies existing case law, which extended the immunity shield to diplomats engaged in private commercial activities. For example, it was held in The Porto Alexandre that a diplomatic agent "may engage in private trading, but ... his immunity ... protects him even from proceedings in respect of his private trading."89 However, the rg64 Act in no way changed, nor indeed addressed, the matter of the immunities of the State itself as to State trading activities. ${ }^{30}$

The strength of the case law tendency to grant sovereign immunity to state-

\footnotetext{
${ }^{84} 466$ PARL. DEB., H.C. (5th ser.) $1_{76}-65$ (I949).

${ }^{85}$ I65 PARL. Deb., H.C. (5th ser.) 926 (1949).

${ }^{8 B} I d$. at 942 .

${ }^{87}$ I74 PARL. DEB., H.C. (5th ser.) 757-58 (195x) (emphasis added).

${ }^{88}$ The Diplomatic Privileges Act 1964, c. 81 , art. $3 \mathrm{I}(\mathrm{I})(\mathrm{c})$. See Bucklcy, The Effect of the Diplomatic Privileges Act 1964 in English Law, BRIr. Y.B. INT'L L. 321, 338-43 (1965-66).

${ }^{80}$ [I920] P. at 37 .

${ }^{\circ 0}$ Bucklcy, supra note 88 , at 363 .
} 
operated enterprises is also evident in decisions pertaining to state-owned vessels. A recent case is illustrative in this regard. ${ }^{11}$ Defendants' vessel, The Bulgaria, was seized and arrested, upon application by plaintiff. After making a conditional appearance, defendants offered to obtain bail bond as a condition of release of the ship, since defendants desired to sail before the court would have had the opportunity to set aside plaintiff's writ on the grounds of sovereign immunity. However, defendants were concerned that posting bond would be construed as a voluntary submission to the court's jurisdiction and, thus, applied for leave to post the bond with the condition that such action would not prejudice defendants' right to move that the plaintiff's writ be set aside. The court allowed the defendants to do so, thereby assuring availability of the sovereign immunity defense.

III

\section{Contracts and Conflicts of Law}

The principle of lex loci contractus is fundamental to English law. As applied to Anglo-Soviet transactions, the rule was tested in the context of events following the revolution in Russia in the case of Perry $\nu$. Equitable Life Assurance Society. ${ }^{92}$ In I903, plaintiff took out a life insurance policy with the defendantinsurer for a specified amount payable at defendant's office in St. Petersburg. By the terms of the policy, all payments were to be made in Russia. Accordingly, plaintiff paid all premiums in Russia until I9I7, and thereafter made subsequent payments in London until rgrg. By the terms of an Imperial Decree of 1889, which were incorporated in the policy, it was provided that all disputes in connection with insurance operations should be decided according to Russian law and in Russian courts. After the Bolsheviks seized power, a monopolization decree was issued in December, I9r8, whereby all forms of insurance were made a state monopoly. A year later, a cancellation decree was issued, abolishing life insurance altogether and annulling existing contracts. Having been prevented by governmental edicts from suing on the policy in Russia, plaintiff instituted an action in England for a judgment declaring that defendant-insurer was liable to him under the policy. The court found for the defendant on the basis that since the proper law governing the contract was Russian law, the effect of the decrees of I9I8 and I9r9 was to annul the policy.

Also accepting the predominance of Soviet law is Re Banque des Marchands de $\mathrm{Moscou}^{93}$ a case arising out of the dissolution and nationalization of a bank by the Soviet government. Under a decree in December, 1917 , the assets and liabilities of the bank were taken over by the State Bank. In 1932, a winding-up order was made in England with respect to the bank, and the court-appointed liquidator received the bank's assets in England and accepted claims against the

\footnotetext{
${ }^{11}$ [1964] 2 Lloyd's List L.R. 524.

${ }^{02} 45$ T.L.R. 468 (1929).

${ }^{03}$ [1952] I All E.R. 1269.
} 
assets. Among the claimants was the Royal Exchange Assurance, which sought to prove that at the time of nationalization it had certain sums deposited in accounts with the bank in the Soviet Union and had deposited certain securities for safe custody. ${ }^{94}$ Arguing from a corollary of the rule propounded in the case of $R e$ Russian Bank for Foreign Trade, ${ }^{95}$ wherein it was held that Soviet nationalization decrees could not extinguish debts which in English law were regarded as being locally situated in England, the court extended principles propounded in Princess Paley Olga $v$. Weisz, ${ }^{96}$ and held that the claims of the Royal Exchange Assurance were governed by Russian law. Applying such law, the court held that the effect of the nationalization decree was to extinguish Royal's rights against the bank and that, therefore, there was no existing debt owed by the bank to Royal at the date of the winding-up order. Any claim by Royal subsequent to the decree could properly be made only against the State Bank. ${ }^{97}$ Further, applying the principle that "a bailee of goods who has been evicted by title paramount has no longer any liability under the bailment," 98 the court concluded that the action of the Soviet government was such that the bank could properly plead that it had been evicted by title paramount ${ }^{99}$ and would therefore be discharged from liability.

Applicability of the law of the jurisdiction appropriate under principles of conflicts of law is also demonstrated in the case of Carl-Zeiss-Stiftung $v$. Rayner $\mathcal{E}$ Keeler, Ltd.100 In that case, an East German corporation (Carl-Zeiss-Stiftung) brought an action against defendants, including the West German Zeiss corporation (Zeiss-Heidenheim), contending that the latter corporation had used plaintiff's name without consent in relation to business and goods. Plaintiff further alleged that Zeiss-Heidenheim had passed off its goods as those of plaintiff. The Zeiss enterprises had traditionally been centered in a district later incorporated within the East German zone. Upon departure of the Allies from the region in 1945 , members of the enterprise's boards of management were moved to the Western zone, where Zeiss interests were further developed and expanded. However, continuous management had existed in the Eastern zone. Subsequent to confiscation and nationalization of the Zeiss enterprises by Soviet authorities, certain political changes were instituted by the U.S.S.R. After the Soviets established the German Democratic Republic (G.D.R.) to govern the areas in Germany occupied by the U.S.S.R., the G.D.R. abolished the political subdivision under which the Zeiss interests were organized and created various districts to replace the prior divisions. The governing body (Council of Gera) of the newly-created district assumed the position of di-

os Id. at $127 \mathrm{I}$.

${ }^{95}$ [1933] Ch. 745, 102 L.J. Ch. (n.s.) 309, I49 L.T.R. (n.s.) 65.

so [x929] I K.B. 718, 98 L.J.K.B. 465 , I4I L.T.R. (n.s.) 207. In that case the court held that English tribunals would not inquire into the validity of acts done by a recognized foreign government affecting its own subjects in respect to property situated in its own territory.

${ }^{97}$ [1952] I All E.R. 1274.

${ }^{98}$ Id. at 1275. Accord, Ross v. Edwards \& Co., 73 L.T.R. (n.s.) roo (1895).

90 [1952] I All E.R. I276.

${ }^{100}[1967]$ I A.C. 853 (1966). 
rectors of the Zeiss interests. In litigation in Ig6I, the Supreme Court in East Germany concluded that Carl-Zeiss-Stiftung continued to exist as a legal entity and that the Council of Gera was its special board. An agent of the board authorized an action to be brought in the English courts against Zeiss-Hiedenheim. Defendant contended that the action was being brought without the proper authorization of Zeiss interests, thereby bringing into issue the authority of the Council of Gera to govern and represent the foundation and to authorize English solicitors to bring a passing-off action in the name of Carl-Zeiss-Stiftung. The issue of the Council's authority, interestingly, had been litigated in the Federal High Court in West Germany, which held that Carl-Zeiss-Stiftung was not properly before it inasmuch as the Council of Gera had no authority to represent the enterprise.

In Ig64, a British official certified to the court that the British government recognized only the U.S.S.R. as sovereign with respect to the Eastern zone of Germany. The court, in turn, held that the G.D.R. must be regarded as a subordinate organization acting with the consent of the government of the U.S.S.R. and thereby deriving authority from the sovereignty of the U.S.S.R. ${ }^{101}$ Since a foreign corporation is governed by the law of its domicile, the capacity of plaintiff to bring the action is determined by East German law. ${ }^{102}$ It appeared that East German law was clearly to the effect that Carl-Zeiss-Stiftung still exists as a "juristic person"103 and that the Council of Gera was entitled to act as the enterprise's special board. ${ }^{104}$ Consequently, full effect was given to East German law, thereby confirming the propriety of the action being instituted pursuant to authorization by the Council of Gera.

\section{IV}

\section{COUNTERCLAIMS}

English law governing counterclaims against a sovereign in principle allows maintenance of such a claim if necessary for purposes of doing justice and if the counterclaim directly relates to matters connected with the principle claim. The reticence toward adopting an expansive judicial attitude concerning counterclaims is reflected in the case of South African Republic v. Transvaal Northern $R y .^{105}$ In that case, an action was brought by the government of the South African Republic for the appointment of a new trustee of funds generated under a concession to a railroad company. The defendant filed a counterclaim for an amount allegedly owed by the government under the concession. Upon plaintiff's application, the court dismissed the counterclaim on the grounds that it was too indirectly related to the subject matter of the principal action. In accord with the strict principles propounded

\footnotetext{
${ }^{102} I d$. at 906.

${ }^{102}$ Id. at 929 (opinion of Hodson, L.J.).

${ }^{103}$ Id. at 939 (opinion of Guest, LJ.).

${ }^{106}$ Id. at 949 (opinion of Upjohn, L.J.).

${ }^{105} 67$ L.J.Ch. (n.s.) 92 (1897).
} 
in Transvaal is Union of Soviet Republics v. Belaiew, ${ }^{108}$ an Anglo-Soviet case relating to the ownership of certain government documents. The Soviet government instituted a suit to obtain the documents, which dated back to Igr6 when the Russian Government Committee, of which the defendant was a member, was established in London by the Imperial Russian Government. The committee was continued by the Russian Provisional Government after the onset of the revolution and actively functioned until rgI8. The documents related primarily to financial obligations incurred by the Government Committee and were legally the property of the governments. Upon the committee's termination, the documents were tendered to a special board of trustees, appointed by the charge d'affaires of the Russian Provisional Government, of which board defendant became president. Upon institution of the suit, defendant set up a contention by counterclaim that he was entitled to a lien on the documents until he had received indemnification by the Soviet government with respect to actions pending against defendant arising out of the matters to which the documents related. The court dismissed the counterclaim, although it reiterated the principle that such a claim can be maintained against a plaintiff-sovereign if the counterclaim is confined to matters immediately connected with the principal claim. The reason for dismissal was that the indemnity claimed by the defendant was not in respect to any liability incurred by him qua custodian of the documents, even though the claims against defendant arose in connection with matters pertaining to the documents.

\section{ConcLusion}

The future of Anglo-Soviet trade is largely a matter of conjecture. The discernible pattern governing past and present trade relations is characterized by Soviet willingness to accept a legal framework ordinarily employed in accords between market economy countries, ${ }^{107}$ as evidenced by the bilateral agreements beginning in 1921, with the inclusion of certain formalities customarily found in trade agreements between socialist countries. The explanation for Soviet flexibility may lie in part in the generous attitude of English law toward state trading and in the comparative advantage obtained by virtue of most-favored-nation arrangements. Whether a change in English law or policy restricting either of these factors would lead to alteration of the legal structure of commercial relations must remain a matter of speculation.

${ }^{100}$ I34 L.T.R. (n.s.) 64, 42 T.L.R. 21 (I925).

${ }^{107}$ See Hoya, supra note $I$, at 45. 